Ann. Biol. anim. Bioch. Biophys., I975, 15 (2), 297-299.

\title{
NORMAL FERTILITY INDUCED IN COW BY DOUBLE SHORT TREATMENT WITH CHLORMADINONE ACETATE (CAP)
}

\author{
J. REY
}

Instytut Zootechniki, Zaklad Biologii Hodowlanej

32 - 083 Balice k. Krakowa (Pologne)

After a 9-day treatment by $25 \mathrm{mg}$ of CAP daily, fertility (pregnancy rate) at oestrus following the induced cycle seems to be related to the duration of that cycle. When the length of the induced cycle is not longer than 25 days, fertility rate is similar to that after a normal oestrus (62.5 vs 59.I p. Ioo). On the other hand fertility is very low (7.7 p. I0O, $\mathrm{P}<0.01$ ) after a cycle longer than 25 days (table $\mathbf{I}$ ).

TABLE I

Fertility rates at induced oestrus in relation to length of cycle after CAP treatment

\begin{tabular}{c|cc}
\hline Cycle & $\begin{array}{c}\text { Length of cycle } \\
\text { (days) }\end{array}$ & $\begin{array}{c}\text { Fertility rates } \\
(\%)\end{array}$ \\
& & $16-36$ \\
Induced & $16-25$ & 37.8 \\
Normal & $26-36$ & $7.7^{* *}$ \\
(untreated controls) & $18-25$ & 59.1 \\
\hline - & & \\
\hline
\end{tabular}

If a second 9-day treatment with $25 \mathrm{mg}$ of CAP daily follows $\mathrm{I} 2$ days later, 93 to 97 p. Ioo of treated cows exhibit oestrus within 5 to 7 days. Fertility is significantly higher $(\mathrm{P}<0.05)$ than in cows treated once with CAP for 9 days (74.2 p. roo vs 48.4 p. Ioo) (table 2). 
TABLE 2

Fertility at induced oestrus either by one or two successive CAP treatments

(CAP treatments : 9 days at a daily dose of $25 \mathrm{mg}$ orally.

Oestradiol valerate (EV) : $5 \mathrm{mg}$ IM at the beginning of CAP treatment)

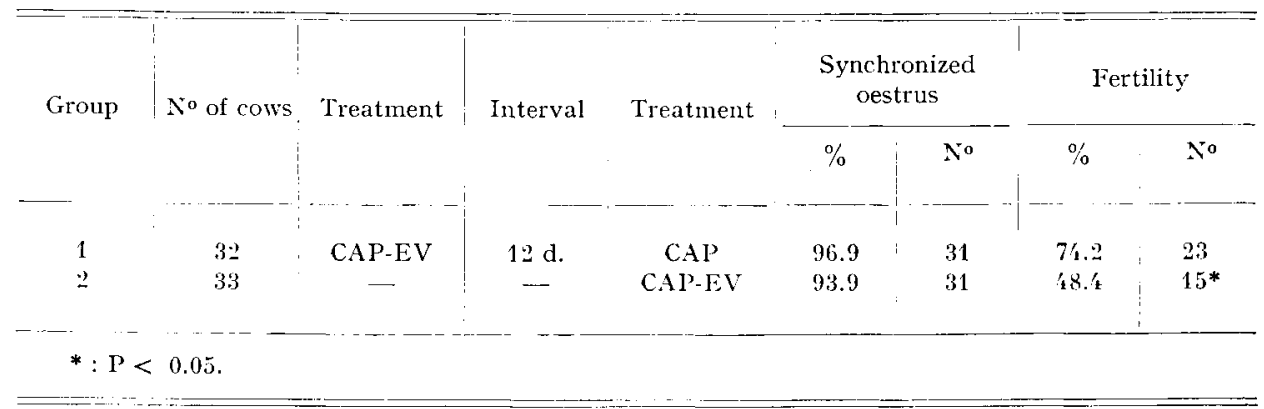

In a following trial, 4 groups of lactating cows receiveid CAP in two successive treatments associated or not with an injection of $5 \mathrm{mg}$ of estradiol valerate at the beginning of one or both treatments.

The fertility rates are $55.2,60.7,62$. I and 63.0 , respectively; they do not differ from each other, indicating that estradiol valerate has no beneficial effect.

Fertility rates of treated cows are higher than those of control cows (4I.7 p. IOo) during the same 25 -day period (table 3 ).

\section{TABLE 3}

Onset of oestrus and fertility rate at induced oestrus after 2 successive CAP treatments, with or without oestradiol valerate injection $(E V)$

(For CAP treatments and EV injection, see table 2)

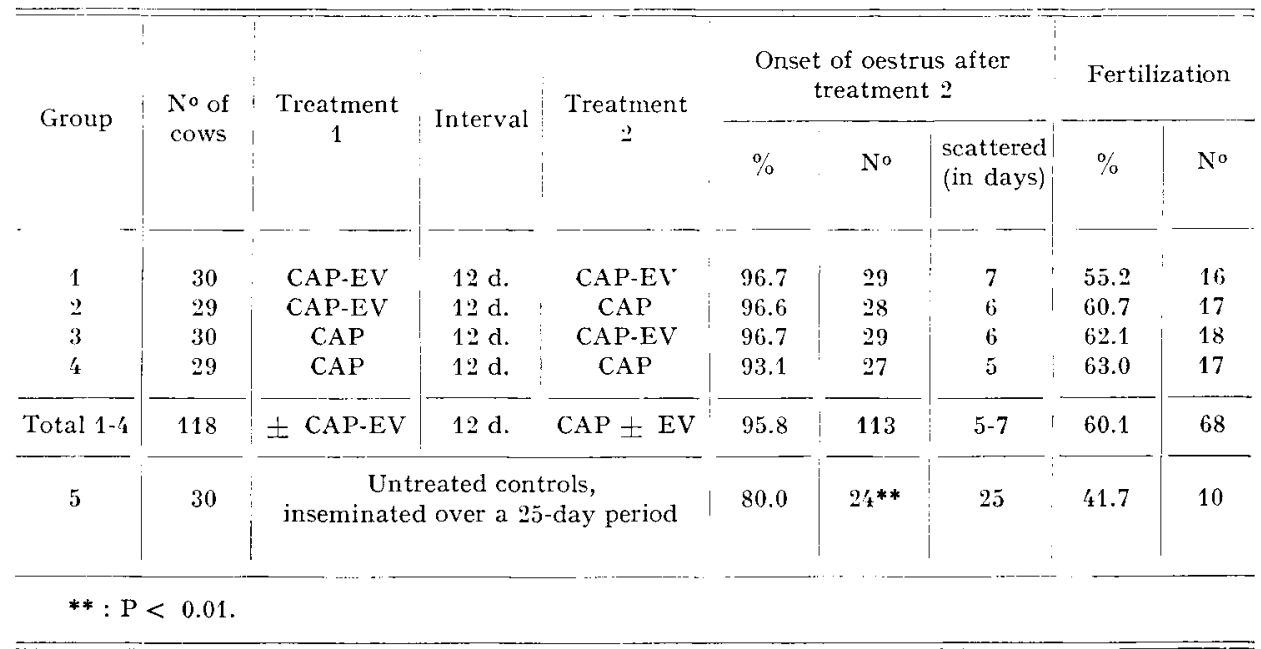

Colloque : Control of sexual cycles in domestic animals. October 27-30, 1974, Nouzilly. 


\section{ACKNOWL,EDGEMENT}

We wish to thank Jenapharm (Jena, East Germany) for donating the CAP («Bovisynchron ») and oestradiol valerate ("Oestradiol-depot").

\section{RÉSUMÉ}

OBTENTION D'UNE FERTILITÉ NORMALE CHEZ LA VACHE PAR UN DOUBLE TRAITEMENT PAR UN PROGESTOGÈNE (CAP)

Chez la Vache, deux traitements successifs $25 \mathrm{mg} \mathrm{CAP} / \mathrm{jour}$ pendant 9 jours, séparés de I 2 jours permettent d'obtenir une bonne synchronisation des œstrus et une fertilité normale à l'œstrus induit. 